Article

\title{
Flavonoids as Potential Drugs for VPS13-Dependent Rare Neurodegenerative Diseases
}

\author{
Piotr Soczewka ${ }^{1}$, Krzysztof Flis ${ }^{1}$, Déborah Tribouillard-Tanvier ${ }^{2,3}{ }^{(\mathbb{D}}$, Jean-Paul di Rago ${ }^{2}$, \\ Cláudia N. Santos ${ }^{4,5}$, , Regina Menezes ${ }^{4,5}$, Joanna Kaminska ${ }^{1}$ (i) and Teresa Zoladek ${ }^{1, *}$ \\ 1 Institute of Biochemistry and Biophysics, Polish Academy of Sciences, Pawinskiego 5A, \\ 02-106 Warsaw, Poland; psoc@ibb.waw.pl (P.S.); kflis@bp.onet.pl (K.F.); kaminska@ibb.waw.pl (J.K.) \\ 2 CNRS, Institut de Biochimie et Génétique Cellulaires, Bordeaux University, CEDEX, 33077 Bordeaux, France; \\ deborah.tribouillard-tanvier@ibgc.cnrs.fr (D.T.-T.); jp.dirago@ibgc.cnrs.fr (J.-P.d.R.) \\ 3 Institut National de la Santé et de la Recherche Médicale INSERM, 33077 Bordeaux, France \\ 4 Instituto de Biologia Experimental e Tecnológica, Av. República, Qta. do Marquês, 2780-157 Oeiras, Portugal; \\ claudia.nunes.santos@nms.unl.pt (C.N.S.); rmenezes@ibet.pt (R.M.) \\ 5 CEDOC - Chronic Diseases Research Center, Faculdade de Ciências Médicas, Universidade Nova de Lisboa, \\ Rua Câmara Pestana n ${ }^{\circ}$ 6, 6-A Edifício CEDOC II, 1150-082 Lisboa, Portugal \\ * Correspondence: teresa@ibb.waw.pl; Tel.: +48-22-592-1304
}

Received: 9 June 2020; Accepted: 17 July 2020; Published: 21 July 2020

check for updates

\begin{abstract}
Several rare neurodegenerative diseases, including chorea acanthocytosis, are caused by mutations in the VPS13A-D genes. Only symptomatic treatments for these diseases are available. Saccharomyces cerevisiae contains a unique VPS13 gene and the yeast vps $13 \triangle$ mutant has been proven as a suitable model for drug tests. A library of drugs and an in-house library of natural compounds and their derivatives were screened for molecules preventing the growth defect of vps $13 \Delta$ cells on medium with sodium dodecyl sulfate (SDS). Seven polyphenols, including the iron-binding flavone luteolin, were identified. The structure-activity relationship and molecular mechanisms underlying the action of luteolin were characterized. The FET4 gene, which encodes an iron transporter, was found to be a multicopy suppressor of vps13⿻, pointing out the importance of iron in response to SDS stress. The growth defect of vps13 $\Delta$ in SDS-supplemented medium was also alleviated by the addition of iron salts. Suppression did not involve cell antioxidant responses, as chemical antioxidants were not active. Our findings support that luteolin and iron may target the same cellular process, possibly the synthesis of sphingolipids. Unveiling the mechanisms of action of chemical and genetic suppressors of vps $13 \triangle$ may help to better understand VPS13A-D-dependent pathogenesis and to develop novel therapeutic strategies.
\end{abstract}

Keywords: yeast model; neurodegenerative diseases; VPS13 genes; drug repurposing; luteolin; tolcapone; FET4 gene; iron; sphingolipid biosynthesis; $\operatorname{csg} 2 \Delta$

\section{Introduction}

Neurodegenerative diseases (NDs) are a group of age-related diseases characterized by progressive neuronal loss, which manifest in a decline of motor or cognitive function. The most common NDs are Alzheimer's disease (AD), Parkinson's disease (PD), and Huntington's disease (HD). In these diseases, one can observe the presence of protein aggregates which contain amyloid $\beta, \alpha$-synuclein, and huntingtin, respectively [1], as well as defects in various cellular processes [2-4]. These diseases are among the most investigated NDs. However, some NDs are very rare and attract much less attention. Such an ND is chorea-acanthocytosis (ChAc), with about 1000 cases estimated worldwide [5]. ChAc is caused by mutations in VPS13A gene [6,7], one of the four VPS13 homologs present in the human 
genome [8]; about $90 \%$ of these cause a lack of the VPS13A (or chorein) protein [9]. Mutations in other VPS13 $(B-D)$ genes have also been linked to different diseases with neurological defects [10-14]. Currently, there is no cure for VPS13-associated diseases, only symptomatic treatment is offered. The state of knowledge about these diseases is relatively low and their pathological mechanisms remain unknown $[15,16]$.

To investigate NDs and to find effective therapies, studies on model organisms, such as the yeast Saccharomyces cerevisiae, have been carried out [17]. Yeasts enable research approaches unavailable in higher eukaryotes, such as large-scale genetic screening or functional genomics [18]. Yeast models of most NDs express a pathological variant or overexpress a gene associated with a disease $[17,19]$. Such models can be effectively used to better understand the diseases, identify molecular targets suitable for drug treatment, and select protective molecules [20]. Some of these molecules have been shown to be active in cell culture models and patient-derived cells [21-25]. A study using a PD yeast model identified flavonoids as an active group of compounds against $\alpha$-synuclein toxicity [23].

Flavonoids are a diverse group of chemical compounds found in plants. The core of flavonoids consists of two benzene rings linked by a heterocyclic pyranic ring. Their diversity results from numerous combinations of types, number, and locations of functional groups bound to the core, which influences their biological activity [26,27]. Flavonoids exhibit antioxidant, antiviral, antibacterial, anti-inflammatory, and anticancer activities [26-30]. Some flavonoids have also shown neuroprotective properties in models of $\mathrm{AD}$ and $\mathrm{PD}$, thus being promising drugs for use in clinical trials of NDs [31,32]. The biological effects of flavonoids result from different mechanisms of action, such as the modulation of signaling pathways, antioxidant systems, and metal chelation actions, including iron [27,33].

Iron is necessary for many vital metabolic processes and is the substrate of ROS-generating Fenton reactions. It is an essential cofactor of hemeproteins and Fe-S cluster-containing enzymes, which take part in various cellular processes such as respiration and lipid biosynthesis [34]. Iron homeostasis in yeast is regulated by the transcription factors Aft1 and Yap5, which respond to low and excessive iron availability, respectively $[35,36]$. Aft 1 induces the transcription of genes encoding the components of iron uptake and regulating intracellular iron transport and storage [37]. Depending on iron availability, different iron uptake systems are used by cells. In iron-depleted conditions, yeast cells rely on high-affinity iron uptake systems consisting of Fet3 oxidase and Ftr1 permease. If iron is abundant, uptake is mediated by the low-affinity and low-specificity Fet 4 transporter [38-40]. Another mechanism of iron uptake is the import of iron-siderophore chelates by siderophore transporters belonging to the Arn/Sit family of proteins [37].

As S. cerevisiae contains a homolog of the disease-associated VPS13A-D genes, disease models can be created by its deletion or by introducing mutations corresponding to the ones found in patients. These approaches have been used for modelling and studying diseases associated with VPS13 genes in previous studies [41-43]. The yeast mutant devoid of the VPS13 gene (vps13 $\triangle$ ), as well as the vps13-I2749R strain—carrying a mutation in VPS13 corresponding to one found in a ChAc patient-were viable but showed defects in protein trafficking [9]. We have recently found that both vps13 mutant cells are hypersensitive to very low amounts of the detergent sodium dodecyl sulphate (SDS) [43]. We used this phenotype to screen for multicopy suppressor genes and identified the fragment of the MYO3 gene encoding type I myosin and other genes. The growth defect of the vps $13 \Delta$ deletion mutant can also be suppressed by FK506, which inhibits calcineurin, a calcium-dependent phosphatase [43]. Therefore, the vps $13 \Delta$ strain can be used as a simple model for VPS13-associated diseases, whereas the chemical suppression of vps $13 \Delta$ growth defects can be explored as a tool for drug screening.

In this study, we searched for compounds restoring the vps13 $\Delta$ growth defect in the presence of SDS. The Prestwick library of FDA-approved drugs and an in-house library of natural compounds and their derivatives were screened, leading to the identification of tolcapone and flavonoids, including luteolin, as active chemical suppressors of vps $13 \Delta$ growth defects. Furthermore, these studies allowed for the identification of the structural determinants of their activity. We also found FET4 to be a multicopy suppressor of vps $13 \Delta$. Functional and genetic interactions of luteolin, iron compounds, 
and mutations affecting iron homeostasis and sphingolipid synthesis were also investigated, in order to unveil the possible mechanisms of action of these compounds.

\section{Materials and Methods}

\subsection{Strains, Media, and Growth Conditions}

The E. coli strain DH5 $\alpha$ was used for plasmid propagation. The S. cerevisiae strains used in this study are listed in Table S1. YPD complete medium ( $1 \%$ yeast extract, $2 \%$ tryptone, $2 \%$ glucose, $1 \%$ adenine) or synthetic SC medium $(0.067 \%$ yeast nitrogen base without amino acids, $2 \%$ glucose) with desired supplements (adenine, uracil, amino acids) were used for yeast cultivation. Growth experiments on media with SDS addition were performed using several dilutions of SDS stock solution and images were taken after different time durations, in order to show the most representative and informative results. This experimental approach was necessary, due to the high sensitivity of mutant cells to small changes of final SDS concentration in the plate, which strongly depends on the lot of medium and SDS stock, as well as various physical factors [43]. Plates were incubated at $28{ }^{\circ} \mathrm{C}$. For drop tests, cells were grown overnight in liquid media and cultures were diluted in sterile distilled water to obtain a cell density equal to $\mathrm{OD}_{600} \sim 1$ or $\mathrm{OD}_{600} \sim 0.1$. Subsequently, aliquots of 4 -fold serial dilutions of cultures were spotted onto solid media. Chemical compounds added to the YPD medium can be found in Table S2.

KJK181A vps13 4 , KJK182 csg2 2 vps13 $\Delta$, and KJK183 ipt1 $\Delta$ vps13 $\Delta$ strains were constructed by deletion of VPS13 using the vps13::URA3 cassette. To this end, the strains BY4741, BYcsg2 $\Delta$, and BYipt1 $\Delta$ were transformed with PCR products obtained using pKA475 plasmid (Table S3) as a template and transformants were selected on SC medium without uracil (SC-ura). Genomic integrations were confirmed by PCR on genomic DNA. These strains were used to test SDS sensitivity phenotype and the effect of luteolin and iron salts on cellular growth.

\subsection{Plasmids}

Plasmids used are listed in Table S3. Plasmid pFL44-FET4, bearing a genomic DNA fragment with FET4 gene, was isolated as a multicopy suppressor of vps13-I2749R SDS hypersensitivity phenotype [43] from the pFL-44 genomic bank [44]. The FET4 gene was amplified by PCR and transferred to YEplac181 [45] and pRS425-P ${ }_{\mathrm{GPD}}$ [46] plasmids to obtain YEp181-FET4 and pRS425-P GPD- $^{-}$ FET4, respectively.

\subsection{Drug Screening Assay}

The assay was based on previously described tests $[47,48]$. Briefly, ops13 $\Delta$ cells were grown to early exponential phase, $\mathrm{OD}_{600}$ was adjusted to 0.5 , and $200 \mu \mathrm{L}$ was spread homogenously onto solid YPD media supplemented with $0.03 \%$ SDS $(12 \times 12 \mathrm{~cm}$ square Petri dishes). Sterile filters were placed on the media surface and $2 \mu \mathrm{L}$ of $10 \mathrm{mM}$ drug solution in dimethyl sulfoxide (DMSO) were applied to each filter disc. In this screen, all 1280 compounds from the Prestwick Chemical Library (Prestwick Chemical, Illkirch-Graffenstaden, France; last used April 2017), the majority of which have been approved by Food and Drug Administration, USA, were tested. DMSO was used as a vehicle control. The plates were incubated at $28^{\circ} \mathrm{C}$ for 3 to 5 days. Data were recorded using a Snap Scan 1212 (Agfa, Mortsel, Belgium).

\subsection{Screen of an In-House Library of Natural Compounds and Their Derivatives}

The in-house library of natural compounds and their derivatives (Table S2 [49]) was composed from $5 \mu \mathrm{g} / \mu \mathrm{L}$ stocks in DMSO. An over-night pre-inoculum of vps13 $\Delta$ strain was refreshed and incubated in the shaker at $28{ }^{\circ} \mathrm{C}$ for $5 \mathrm{~h}$. Samples corresponding to $\mathrm{OD}_{600} 0.2$ were taken, diluted to a final volume of $250 \mu \mathrm{L}$, and spread onto YPD for control and YPD $0.03 \%$ SDS medium plates (14 $\mathrm{cm}$ round or $12 \times 12 \mathrm{~cm}$ square). Compounds from the library were applied on filter discs (10, 20, 
and $30 \mu \mathrm{g}$ per spot). Mock-treated cells (DMSO solvent only) served as negative control, and luteolin (identified in a drug screen of Prestwick library, described above) as positive control. The plates were incubated at $28^{\circ} \mathrm{C}$ for 3 to 5 days. Structure-activity relationship (SAR) analysis was carried out by testing sets of compounds of various structures (Table S2). For SAR, $30 \mathrm{mg}$ of compounds were spotted on filter discs put on YPD, YPD + SDS 0.025\%, and YPD + SDS 0.03\% solid media with plated vps $13 \Delta$ strain and observed after 3 to 7 days.

\section{Results}

\subsection{Drug Library Screening Assay Using vps13D Strain and SDS Hypersensitivity Phenotype Revealed} Luteolin and Tolcapone as Active Compounds

We have previously described that the yeast vps13 $\Delta$ mutant exhibits SDS hypersensitivity and showed that this phenotype has the potential for drug screening [43]. In this study, we adapted this phenotype for drug screening assays (Figure 1) [48], in order to identify molecules preventing the lethality caused by VPS13 deletion. As SDS is inherently toxic, compounds reducing its toxic properties could also be identified and, thus, the other phenotype-cadmium sensitivity-was subsequently tested (see below). We screened the Prestwick drug repurposing library (Prestwick Chemical) previously used in such screens [48,50], which contains drugs accepted for use in humans. Active compounds were identified after 3-5 days by the observation of growth zones around the filter. Their activity was then confirmed in independent experiments. Seven drugs were identified as suppressors of vps13 $\Delta$ growth defect and two showing some structural similarities were selected for further analysis: luteolin, a naturally occurring flavonoid present in many fruits and vegetables, and tolcapone, a drug used to treat PD, which is a reversible nitrocatechol-type inhibitor of catechol-O-methyltransferase [51] (Figure 1). Another flavonoid present in the Prestwick library, ipriflavone, was not active (Figure 1). To elucidate the structural determinants important for activity, we performed further analyses (see below).

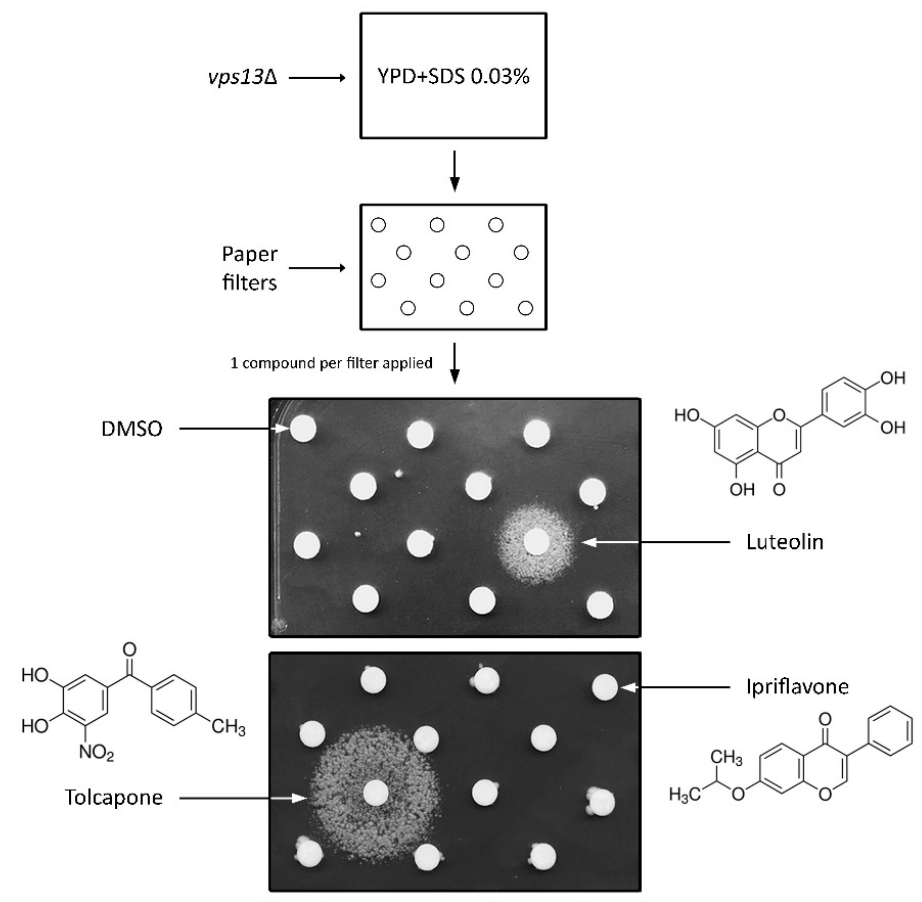

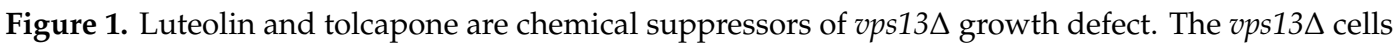
were plated on YPD + SDS $0.03 \%$. Compounds from the Prestwick library were applied on filter discs ( $2 \mu \mathrm{L}$ of $10 \mathrm{mM}$ solution in DMSO). DMSO was used as a negative control. Plates were incubated for 3 days. 
3.2. Screen of an In-House Library of Natural Compounds and Their Derivatives Revealed Six Compounds from Two Structural Classes, Flavonoids, and Tannins

Identification of luteolin as a suppressor of vps13 $\Delta$ growth defect prompted us to screen an in-house library of natural compounds and their derivatives, in order to evaluate further the efficacy of these compounds as chemical suppressors of vps13 $\Delta$ growth defect in the presence of SDS. Of about fifty compounds tested (Table S2), five-namely, quercetin, pentaacetylquercetin, myricetin, fisetin, and corilagin-were shown to restore vps13 $\Delta$ growth on SDS plates (Figure 2). Among all positive-acting drugs, luteolin caused the largest growth zone (Figure S1). Quercetin, myricetin, and fisetin belong to the group of flavonoids with hydroxyl groups positioned in different carbons of the 3-hydroxyflavone backbone. Pentaacetylquercetin can be deacetylated to quercetin and the activity we observed may have been derived from this active metabolite. Corilagin is a member of the group of hydrolysable tannins, which have a complex structure. Kaempferol, which also belongs to the group of flavonoids, was not active (Figure 2). The identified flavonoids were also active as chemical suppressors of cadmium hypersensitivity of vps $13 \Delta$ cells; furthermore, they also improved the growth of the wild-type strain (Figure S2). Thus, we further focused on SAR analysis of flavonoids.

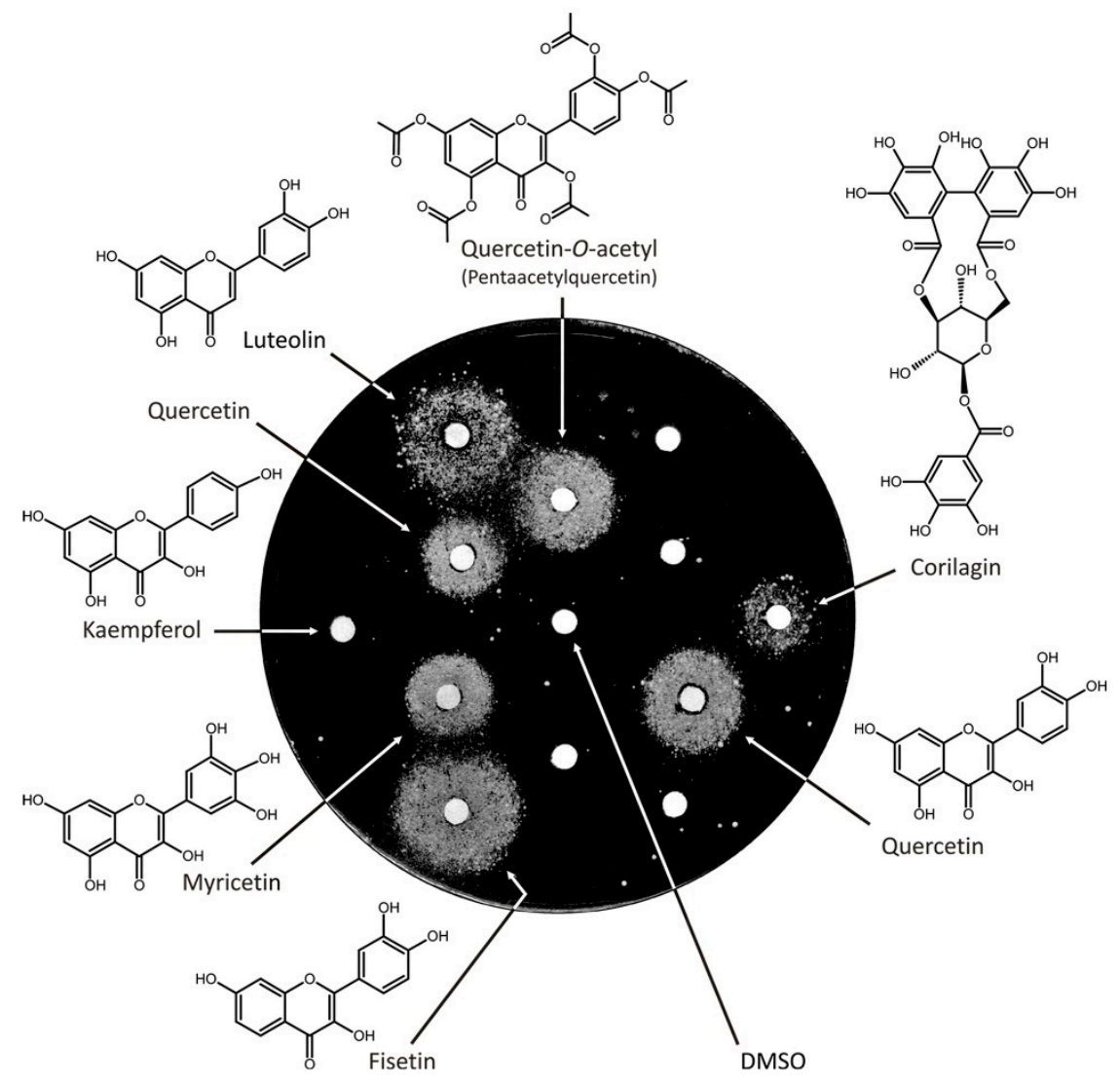

Figure 2. Flavonoids and tannins are chemical suppressors of vps13 $\Delta$ growth defect. The vps13 $\Delta$ strain was plated on YPD + SDS $0.03 \%$. Luteolin was used as a positive control and DMSO as the vehicle control. Kaempferol is indicated as an example of a non-active flavonoid in the conditions used. Compounds were applied at $30 \mu \mathrm{g}$ per spot. Plates were incubated for 5 days. Two quercetin samples from separate stocks were used.

\subsection{Analysis of the Structural Determinants of Flavonoids Activity as vps $13 \Delta$ Suppressors}

To find determinants of flavonoid structure responsible for the vps13 $\Delta$ chemical suppressor activity, we first tested a set of flavonoids varying in the number and position of hydroxyl groups, such as $3^{\prime}, 5^{\prime}$-dihydroxyflavone, $3^{\prime}$, 4' -dihydroxyflavone, $3^{\prime}, 4^{\prime}$, 7-trihydroxyflavone, 3', 4' ${ }^{\prime}, 7,8$-tetrahydroxy 
flavone, butein, scutellarein (4',5,6,7-tetrahydroxyflavone), and 7,8-dihydroxyflavone. The SAR analysis revealed that two is the minimal number of hydroxyl groups and they must be located on adjacent carbons of the B (preferred) or A ring (Figure 3). In addition to the flavones and flovonols, butein $\left(2^{\prime}, 3,4,4^{\prime}\right.$-tetrahydroxychalcone), an intermediate in the biosynthesis of some flavonoids, was also tested. Although butein does not possess a heterocycle (the corresponding part of the $\mathrm{C}$ ring is open), the hydroxyl group positions 3 and 4 are equivalent to positions $3^{\prime}$ and $4^{\prime}$ in flavones. Interestingly, butein was also active (Figure 3), indicating that it is not important whether the $C$ ring is closed or opened, unless other rules are met. These conclusions are also supported by the identification of tolcapone from Prestwick library, which contains A and B rings, but has an open C ring and contains two hydroxyl groups on adjacent carbons (see Figure 1).

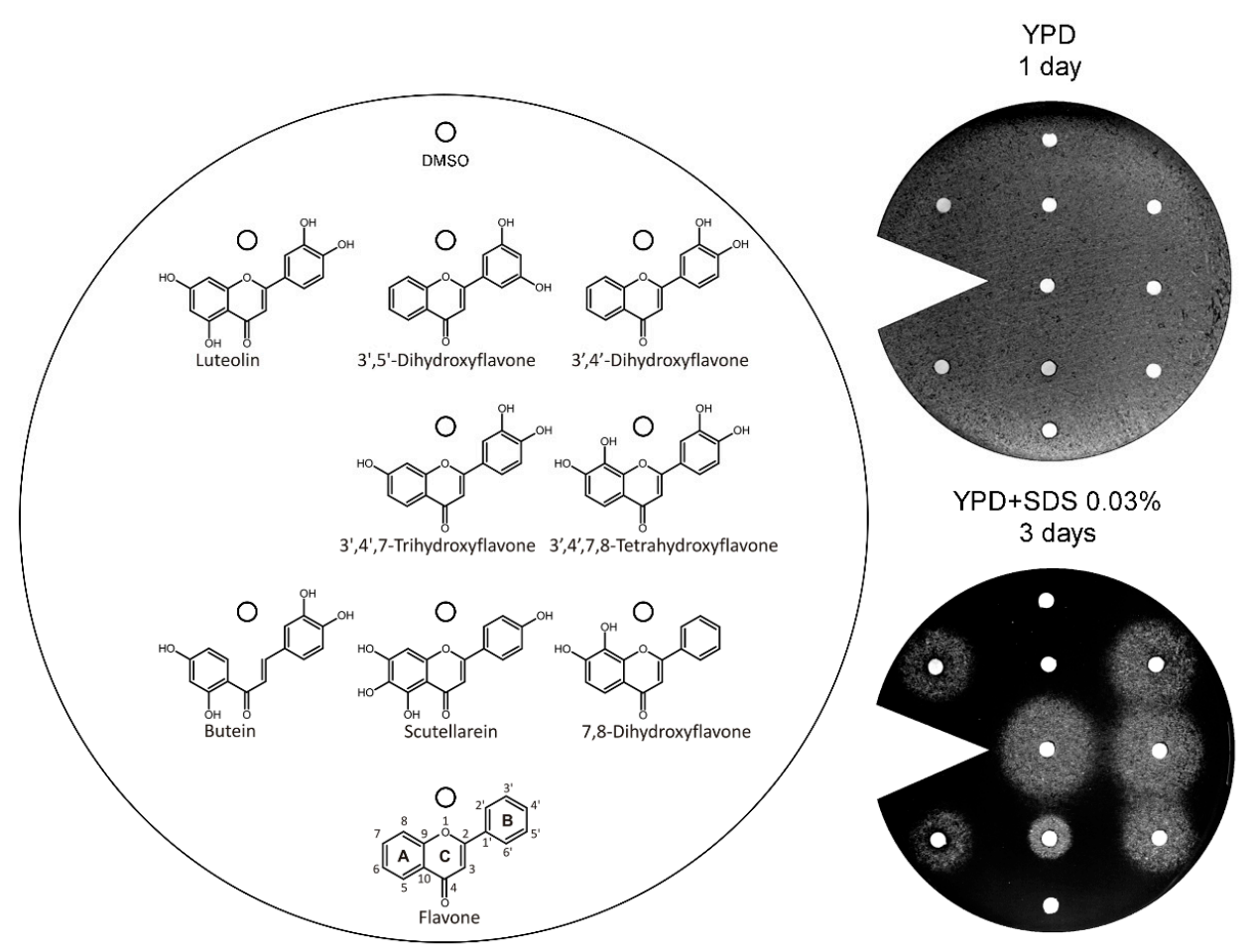

Figure 3. The $v p s 13 \Delta$ growth-restoring activities of various flavonoids. The $v p s 13 \Delta$ strain was plated on YPD + SDS $0.03 \%$ and YPD for control. The structure of compounds, belonging to different structural subclasses, are shown. Luteolin was used as positive control, and DMSO as negative control. Compounds were applied at $30 \mu \mathrm{g}$ per spot, according to the diagram. Plates were incubated for 1 or 3 days.

Then, we asked if other structural elements are important for the activity and tested a second set of flavonoids. This set included luteolin, fisetin, and myricetin, which served as positive controls (see Figure 2); hyperoside (quercetin 3-D-galactoside), which is glycosylated flavonol; taxifolin, cyaniding, catechin and epicatechin, which have various structures with three rings; and flavone as negative control (Figure 4). The analysis showed that the introduction of a glycoside abolished the activity of quercetin. Moreover, the presence of a carbonyl group in the $\mathrm{C}$ ring and a double bond between $\mathrm{C} 2$ and $\mathrm{C} 3$ atoms, in addition to at least two hydroxyl groups in the A or B ring, are also required for activity. These structural features are similar to those previously associated with the antioxidant and metal chelation properties of flavonoids [52-54]. However, several antioxidant molecules, including trolox (present in Prestwick library), kaempferol (Figure 2), and catechin (Figure 4), the latter having higher antioxidant potential than luteolin [54], were not active. Thus, the iron chelating property, not antioxidant activity, is possibly important for $v p s 13 \Delta$ suppression by flavonoids. 


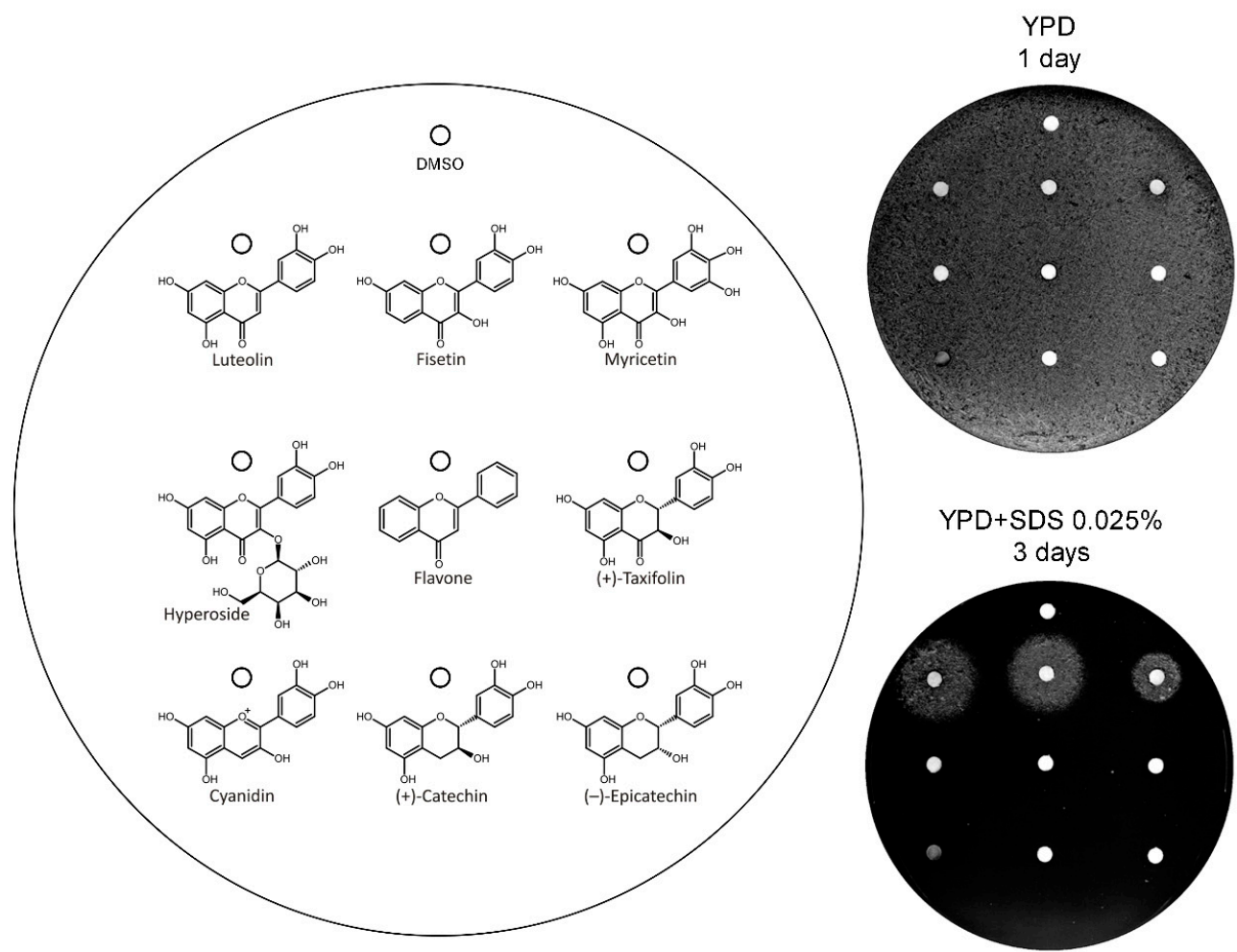

Figure 4. Testing of flavonoids which are hydroxylated in both $3^{\prime}$ and $4^{\prime}$ positions, for their ability to compensate the vps $13 \Delta$-dependent growth defect. The vps $13 \Delta$ cells were plated on YPD + SDS $0.025 \%$ and YPD for control. The structures of compounds are shown. DMSO and flavone were used as negative controls. Compounds were applied at $30 \mu \mathrm{g}$ per spot, according to the diagram. Plates were incubated for 1 or 3 days.

\subsection{The FET4 Gene Encoding Iron Transporter Fet4 Suppresses vps13 $\triangle$ and Mutations Affecting Iron} Transport Result in SDS Hypersensitivity

In a multicopy genomic library screen for suppressor genes of vps13 SDS hypersensitivity phenotype [43], we identified a plasmid containing the FET4 gene encoding a low affinity plasma membrane iron $\left(\mathrm{Fe}^{2+}\right)$ transporter [38] (Figure 5a). This finding indicated the importance of iron transport in the response to SDS stress. However, placing the FET4 gene under the control of a strong constitutive promoter, GPD, caused less efficient suppression, suggesting that FET4 expression must be tightly controlled by the native promoter (Figure 5a). Addition of luteolin to SDS plates improved vps13A growth, irrespective of the presence of FET4. There seemed to be no cumulative effect of exposing cells to luteolin and overexpression of FET4, consistent with the view that both treatments may act on the same pathway. The parental wild-type strain also displayed growth enhancement in response to luteolin, which mitigates SDS toxicity even in the presence of Vps13, but the effect on vps $13 \Delta$ was more pronounced in test conditions. These findings are in line with the view that a moderate increase of iron in vps $13 \Delta$ cells may help to cope with SDS stress.

Further corroboration of the functional association between iron transport and vps $13 \Delta$ growth restoration on SDS-containing plates was provided by the analysis of a set of deletion mutants, devoid of genes encoding iron transporters $f e t 3 \Delta$ and $f e t 4 \Delta$; siderophore transporters $\operatorname{arn} 1 \Delta$, $\operatorname{arn} 2 \Delta$, sit $1 \Delta$, and $e n b 1 \Delta$; or transport factors fre $1 \Delta$ and fre $2 \Delta$. Interestingly, fet $3 \Delta, f e t 4 \Delta, \operatorname{arn} 1 \Delta, \operatorname{arn} 2 \Delta$, fre $2 \Delta$, and enb1 $\Delta$ mutants appeared to be more sensitive to SDS, as compared to the wild-type strain (Figure $5 b$ ), supporting the notion that SDS stress response requires controlled upregulation of iron uptake which apparently does not involve Sit1 siderophore transporter or ferric reductase Fre1, which reduces siderophore-bound iron. Interestingly, the growth of wild-type and these mutant strains was improved by addition of luteolin (Figure $5 b$ ). Iron is easily bound by flavonoids [53,55]; thus, luteolin may 
(directly or indirectly) act by supporting iron transport into the cell, or may affect the same processes for which additional iron is required. Possibly, the impairment of iron transport in response to SDS stress may be the cause of hypersensitivity of vps13 1 , which is corrected either by FET4 upregulation or by luteolin.

(a)

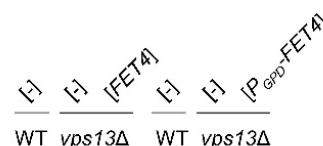

YPD

2 days

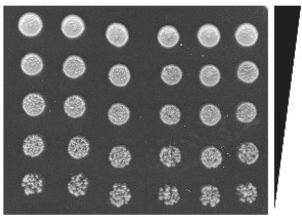

YPD +SDS $0.025 \%$ 3 days
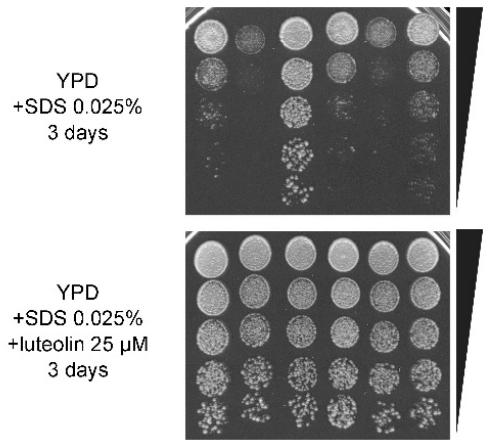

(b)

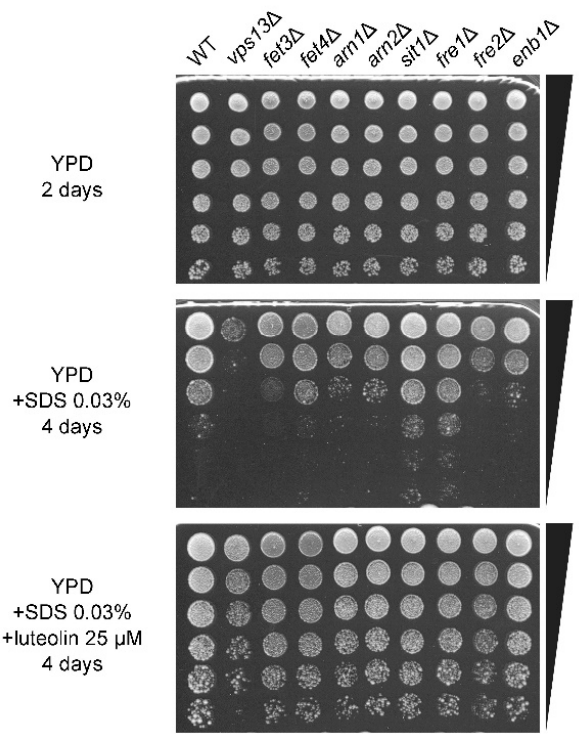

Figure 5. Genetic link between iron transport, luteolin, and SDS hypersensitivity. (a) The vps13 growth defect on SDS media is suppressed by FET4 overexpression and by luteolin. Growth of vps13 $\Delta$ strain bearing a plasmid expressing FET4 from native or GPD promoter, or empty vector, was compared with respective controls by drop test on YPD, YPD + SDS $0.025 \%$, and YPD + SDS $0.025 \%$ + luteolin $25 \mu \mathrm{M}$ plates. Images were taken after 2 or 3 days of incubation. (b) Mutants defective in iron transport are hypersensitive to SDS; this phenotype is suppressed by luteolin. Growth of fet3 $\Delta, f e t 4 \Delta$, arn $1 \Delta$, $\operatorname{arn} 2 \Delta$, sit1 $\Delta$, fre $1 \Delta$, fre $2 \Delta$, and enb1 $\Delta$ strains on YPD, YPD + SDS $0.03 \%$, and YPD + SDS $0.03 \%+$ luteolin $25 \mu \mathrm{M}$ plates was compared with wild-type and $v p s 13 \Delta$ controls by drop test. Images were taken after 2 or 4 days of incubation.

\subsection{Iron Salts and Enterobactin Are Chemical Suppressors of vps $13 \Delta$}

To explore the genetic link between iron transport, luteolin, and SDS sensitivity, we tested various iron compounds for their effect on vps13 $\Delta$ growth on SDS-containing plates. Addition of soluble iron salts, namely iron(II)chloride, iron(III)chloride, and iron ammonium sulfate (Mohr's salt) restored growth of vps $13 \Delta$ cells on SDS plates (Figure 6a). A small zone of inhibition close to the filter was observed, indicating that high iron ion concentrations were toxic. These results may indicate that $v p s 13 \Delta$ cells require an excess of iron to respond to SDS stress or that they have an iron deficit. An argument against the last possibility is the fact that the transcriptional activation of FET3 and CTH2, which are involved in a signaling pathway responding to iron deficiency [56], was unchanged in vps13 $\Delta$, compared to the wild-type and upon SDS stress, as tested using the respective lacZ reporter fusions (Figure S3a,b). Moreover, the sensitivity of vps13 $\Delta$ to ferrozine, a strong iron chelator, was similar to that of the wild-type strain (Figure S3c), suggesting that iron levels were similar in both strains.

We also tested whether the growth phenotype of vps13 $\Delta$ was affected by enterobactin (also known as enterochelin; Figure 6b), which is a high affinity siderophore belonging to the catechol group of compounds. It is found in bacteria such as Escherichia coli and Salmonella typhimurium. Enterobactin bound to $\mathrm{Fe}^{3+}$ is transported by the Enb1 transporter into yeast cells [57]. Interestingly, enterobactin restored growth of vps13 $\Delta$ on SDS-containing plates (Figure 6c). Enterobactin also contains structural elements, such as two hydroxyl groups on adjacent carbons of the benzene ring and a carbonyl group 
in the central ring (Figure 6b), which we found important for vps13 $\triangle$ SDS phenotype suppression by flavonoids in the SAR analysis. This suggests that enterobactin and flavonoids, such as luteolin and fisetin, may suppress the growth phenotype of vps13 $\Delta$ by a similar iron-dependent mechanism.

(a)

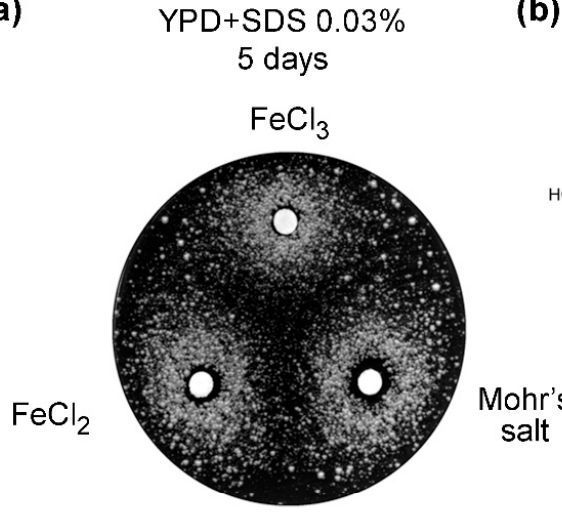

(c)

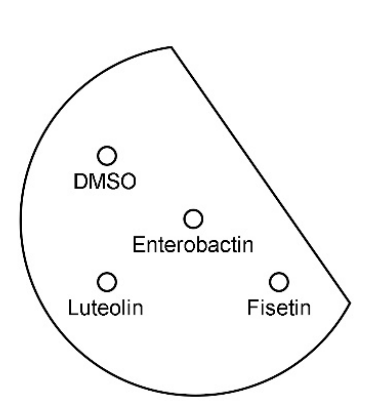

(b)

\section{Enterobactin}<smiles>O=C(N[C@@H](COC(=O)[C@H](COC(=O)[C@@H](NC(=O)c1cccc(O)c1O)C(=O)N[C@H](COC(=O)c1cccc(O)c1O)C(=O)O)NC(=O)c1cccc(O)c1O)C(=O)O)c1cccc(O)c1O</smiles>

YPD+SDS $0.03 \%$

5 days

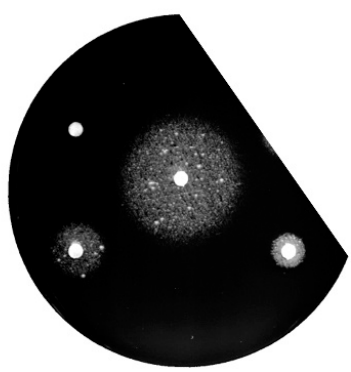

Figure 6. Iron salts and enterobactin restore growth of vps13 $\Delta$ cells on SDS plates. (a) The vps13 $\Delta$ strain was plated on YPD $+\mathrm{SDS} 0.03 \%$. Iron salts $\left(\mathrm{FeCl}_{3}, \mathrm{FeCl}_{2}\right.$, and Mohr's salt $\left.\mathrm{Fe}\left(\mathrm{NH}_{4}\right)_{2}\left(\mathrm{SO}_{4}\right)_{2}\right)$ were applied at $10 \mu \mathrm{L}$ of $1 \mathrm{M}$ solution per spot. Plates were incubated for 5 days. (b) Structure of enterobactin. (c) The vps $13 \Delta$ strain was plated on YPD + SDS $0.03 \%$. Enterobactin and flavonoids were applied at $10 \mu \mathrm{g}$ per spot. Luteolin and fisetin were used as positive controls, and DMSO as negative control. Plates were incubated for 5 days.

\subsection{Characterization of the Possible Mechanism of Flavonoids Action}

The importance of iron supply in the response of vps13 $\Delta$ cells to SDS turned our attention to iron-dependent cellular processes, which might be essential under this stress condition. Iron ions are cofactors of heme proteins, Fe-S clusters proteins, and other enzymes, which take part in several processes, including iron transport and lipid biosynthesis [34]. Lipid biosynthetic pathways, producing unsaturated fatty acids, sterols, and sphingolipids, contain heme proteins. Thus, iron co-ordinates the synthesis of various lipids in response to cell needs. SDS, as a detergent, disrupts the cell wall and plasma membrane; thus, the remodeling of the cell wall and lipid composition of the plasma membrane are crucial in the SDS response $[43,58,59]$. Sphingolipid biosynthesis has previously been found to be important for SDS tolerance. Cells devoid of IPT1, encoding inositolphosphotransferase responsible for the last step in the biosynthesis of the major plasma membrane sphingolipid mannose-(inositol-P) $)_{2}$-ceramide [M(IP)2C] [60], and CSH1 and SUR1, encoding mannosylinositol phosphorylceramide (MIPC) synthase catalytic sub-units [61,62], have been shown to be hypersensitive to SDS [58]. Thus, the sensitivity of $\operatorname{csg} 2 \Delta$ and ipt $1 \Delta$ mutants, defective in complex sphingolipid biosynthesis, to various SDS concentrations, and their genetic interaction with vps $13 \Delta$ mutation in these conditions were tested. The $\operatorname{csg} 2 \Delta$ strain, devoid of a protein required for the mannosylation of inositolphosphorylceramide (IPC), was more sensitive than ipt $1 \Delta$ to SDS, as $\operatorname{csg} 2 \Delta$ grew slower while ipt $1 \Delta$ grew at a similar rate to the wild-type strain on YPD + SDS $0.015 \%$ (Figure 7). The effect 
of both these mutations was additive with vps13 $\Delta$, as $\operatorname{csg} 2 \Delta$ vps $13 \Delta$ did not grow on YPD + SDS $0.015 \%$ and ipt $1 \Delta$ vps $13 \Delta$ stopped growing when the SDS concentration was higher (YPD + SDS 0.02\%; Figure 7) while respective single mutants grow in these conditions. These negative genetic interactions suggest that Vps13 contributes to cell survival during SDS stress in parallel to complex sphingolipid biosynthesis pathways. Interestingly, when suppression by luteolin or $\mathrm{FeCl}_{2}$ of the respective mutants was studied, it was observed that $\operatorname{csg} 2 \Delta$, ipt1 $\Delta$, and the respective double mutants $\operatorname{csg} 2 \Delta$ vps $13 \Delta$ and ipt $1 \Delta$ vps $13 \Delta$ were suppressed (Figure 7). Thus, MIPC and M(IP) $)_{2} \mathrm{C}$, the last two products of the sphingolipid biosynthesis pathway, seemed not to be important in the action of luteolin and $\mathrm{FeCl}_{2}$ on vps $13 \Delta$ cells. As vps $13 \Delta$ and $\operatorname{csg} 2 \Delta$ or ipt $1 \Delta$ showed genetic negative interaction and luteolin or iron suppressed growth defect of single and double mutants, we conclude that there must be a pathway, independent of the Vps13 protein and the synthesis of complex sphingolipids or the upregulation or downregulation of which, by the administration of luteolin or iron, is helpful under SDS stress.
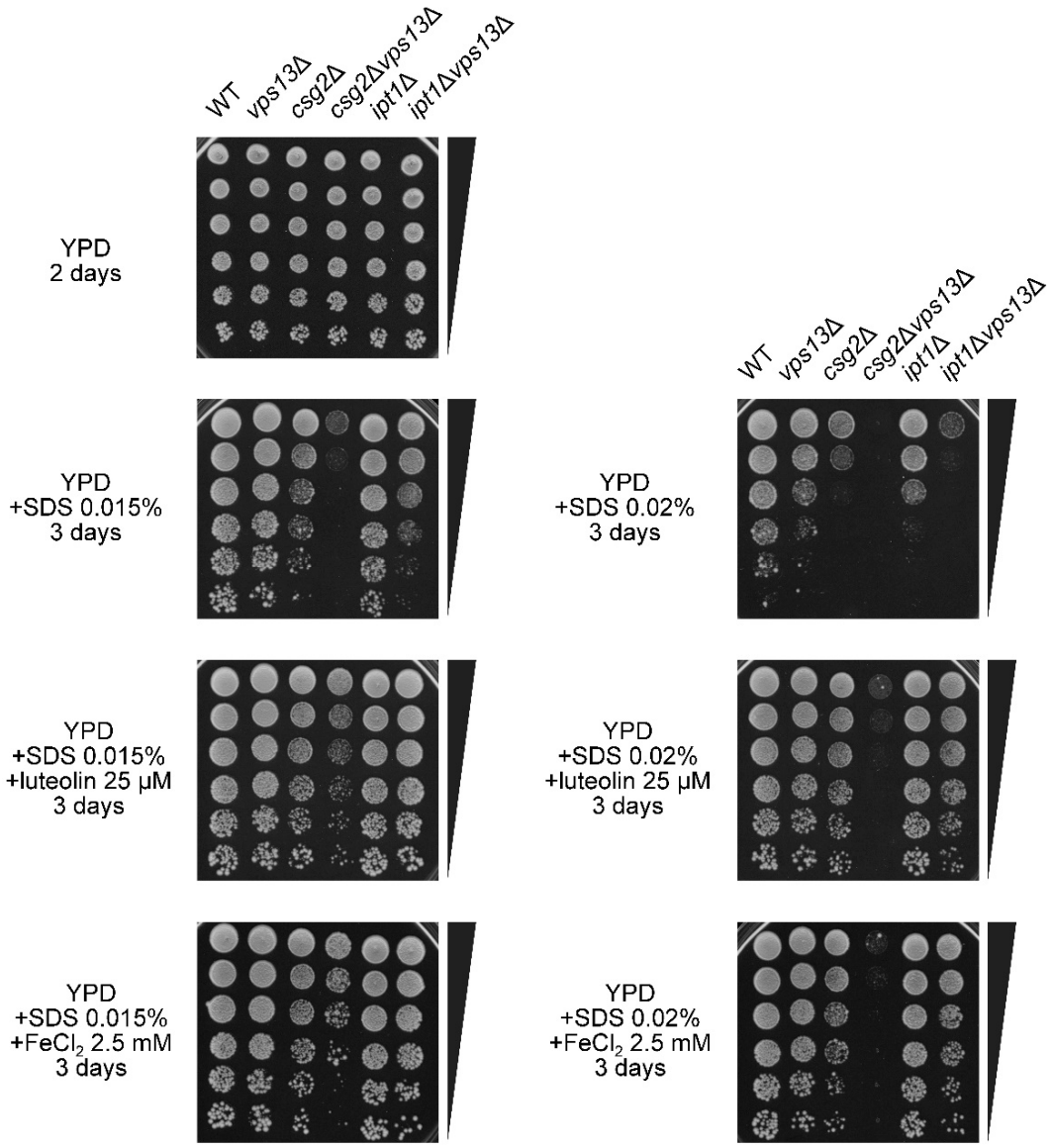

Figure 7. The ipt1 $\Delta$ and $\operatorname{csg} 2 \Delta$ mutations causing defects in complex sphingolipid biosynthesis are suppressed by luteolin and iron salt, and negatively interact with vps13 $\Delta$. Growth of wild-type, ops13 $\Delta$ (KJK181A), csg2 $\Delta$, ipt1 $\Delta$, and the respective double mutants on YPD plates containing SDS was compared by drop test. The effect of luteolin and $\mathrm{FeCl}_{2}$ on growth is also shown. Images were taken after 2 or 3 days of incubation.

\section{Discussion}

The pathogenesis of neurodegenerative diseases caused by mutations in VPS13A-D genes is not well understood and no effective treatment is available. Simple model organisms, such as the yeast $S$. cerevisiae, offers opportunities to improve our understanding of cellular pathogenic processes and perform drug repurposing screening. This is possible by using mutations in the yeast VPS13 gene encoding the Vps13 protein, the orthologue of human VPS13A-D gene products [9]. In this paper, we screened the Prestwick library and an in-house library of natural compounds and their 
derivatives and identified several polyphenols, including the flavone luteolin, for protective compounds overcoming some of the defects caused by Vps13 deficiency. These defects can also be reversed by overexpression of FET4, encoding an iron transporter, and the addition of iron salts or iron-binding siderophores to the medium. This indicates the importance of cellular iron concentration for $v p s 13 \Delta$ cells to survive under stress and provides a link to the metabolic pathway, which we conclude to be involved in the mechanism of luteolin action - the sphingolipid biosynthesis pathway.

Screening of the Prestwick drug repurposing library and an in-house library of natural compounds and their derivatives revealed several polyphenols from the group of flavonoids and tannins as able to overcome the defects caused by Vps13 deficiency. Besides the SDS hypersensitivity phenotype used in the screen, the cadmium hypersensitivity of vps13 cells was also effectively suppressed, showing that the mechanism of action of the selected compounds was not SDS-specific but more general. However, some transport defects, such as the defect of Sna3-GFP transport to the vacuole [42] were not suppressed (unpublished results). Flavonoids such as luteolin, quercetin, fisetin, and myricetin are best-known for their antioxidant and metal chelation activities [53,54]. Quercetin, together with (-) epigallocatechin-3-gallate, was found previously as a compound which has strong activity to restrain $\alpha$-synuclein toxicity in a yeast model system of PD [23]. From the SAR analysis, the authors concluded that these compounds act by virtue of antioxidant and metal chelating properties; these conclusions were also supported by the observation that iron salt negatively affected this model system. Our SAR analysis similarly showed that the suppressor activity of flavonoid compounds correlated with the same structural requirements as for their iron-binding and antioxidant properties. However, anthocyanins and anthocyanidins, both very potent antioxidants from another structural group, which were present among the compounds in the in-house library of natural compounds, as well as several other antioxidants that we tested, such as trolox, kaempferol, and catechin [54], were unable to restore the growth of vps $13 \Delta$ cells in the presence of SDS. Altogether, the data suggest that the protective action of flavonoids is rather not related to antioxidant action but, instead, depends on mechanisms linked to their metal-binding properties.

In contrast to the results obtained by testing flavonoids using the yeast model of PD [23], the addition of iron salts showed positive effects in our model system, suggesting that increased cellular levels of iron can help to overcome disturbances caused by Vps13 deficiency. In support of this idea, the iron siderophore enterobactin, which transports iron into cells, was also a very potent suppressor of vps13 $\triangle$. Moreover, in our genetic screen, the FET4 gene, encoding a low-affinity iron transporter, was found as a multicopy suppressor of the vps13 $\Delta$ growth defect, showing again that increased iron transport into the cell is helpful in this condition. Interestingly, luteolin restored the growth of vps13 cells regardless of the presence of multiple copies of FET4; thus, the effect of these two factors was not additive, suggesting that they act on the same process. Possible mechanisms of flavonoids and iron action involve binding to specific proteins, affecting metabolic or signaling pathways, or changing gene expression to induce a protective response in cells against SDS stress [63,64].

Increased sensitivity to SDS suggests the defective structure of cellular membranes in the vps13 mutant. Membranes are composed of a complex mixture of lipids, including sphingolipids. The composition of membrane lipids changes along with the secretory pathway in S. cerevisiae: Sphingolipids are generated in the ER and Golgi, then delivered to the plasma membrane where they are most abundant [65] and play a significant role in responding to various stresses, both as building components and as signaling molecules. By using the yeast genetic approach, we have demonstrated the link of Vps13 and luteolin with a sphingolipid pathway. The ipt1 $\Delta$ and $\operatorname{csg} 2 \Delta$ mutations causing defects in complex sphingolipid biosynthesis are suppressed by luteolin and iron salt, and negatively interact with vps13 $\Delta$. One may find indirect connections between Vps13 and sphingolipids through the analysis of previously published data. Noteworthy, ops13/soi1 mutants were originally selected in the screen for suppressors of kex2 mutation disturbing Kex2 protease activity in late Golgi [66] and it was further documented that vps13 mutation affects retrograde traffic of proteins (such as Vps10 receptor) between endosome and late Golgi [67]. As defects in retrograde vesicular transport between endosomes 
and Golgi apparatus result in disturbances in sphingolipid biosynthesis [68], this led to the assumption that the vps13 mutant may have disturbed sphingolipid biosynthesis as well. Moreover, the first step of complex sphingolipid synthesis-the conversion of ceramide to IPC—is essential for the viability of the cell and its regulation involves processing by Kex2 protease [69]. As it has been documented that vps 13 affects wild-type Kex2 cycling between trans Golgi and endosomes [67], vps $13 \Delta$ mutation may negatively affect IPC levels. In addition, examination of reporters for different lipids showed that prospore membranes in vps13 cells have reduced levels of phosphatidylinositol-4-phosphate (PI(4)P), phosphatidylinositol-4,5-bisphosphate (PI(4,5)P2), and phosphatidic acid [70]. Reduction of the latter two lipids could account for an effect on PI(4)P levels [71,72] which, in turn, may also negatively affect IPC levels [73] in vps $13 \Delta$ cells as well. Sphingolipid homeostasis is regulated by complicated sensing and feedback mechanisms, which involve signaling pathways regulating the L-serine:palmitoyl-CoA acyltransferase (SPT), the first enzyme of the sphingolipid biosynthesis pathway [74,75], and changed response of cells to myriocin - the inhibitor of this enzyme - can indicate disturbances in sphingolipid biosynthesis $[68,71,76]$. Possible defects in sphingolipids in vps13 cells which are also resistant to myriocin [68] require further study.

Sphingolipid synthesis is also linked to iron, as high iron levels cause an increase of total sphingolipid precursors, such as long-chain bases (dihydrosphingosine and phytosphingosine) and their phosphate derivatives, where decreasing these levels by myriocin treatment increases yeast tolerance to high iron. Sphingolipids play a signaling role in iron response, as the loss of Pkh1 and Ypk1 kinases [64], which respond to and regulate sphingolipid levels, increases iron tolerance in yeast [77]. We did not observe the hallmark of iron deficiency in vps $13 \Delta$ mutant cells and no iron deficiency was found in the vps13-D716H mutant by others [78]; however, increased iron levels in response to SDS might be helpful in stress defense. Interestingly, sphingolipid homeostasis is also a target of luteolin in human cancer cells [79]. Thus, the addition of luteolin or iron salts to the SDS-containing medium may correct defects of Vps13 deficiency and promote growth by affecting the synthesis of sphingolipid precursors.

Dysregulation of sphingolipid metabolism is involved in a great deal of neurodegenerative disorders, manifesting in neurological symptoms as sphingolipids are highly enriched in the nervous system, where they play important regulatory roles. For example, mutations in genes encoding sub-units of SPT have been shown to cause sensory and autonomic neuropathy type 1 (HSAN1) [80]. Defects in retrograde vesicular transport have been shown to cause disturbances in sphingolipid biosynthesis and result in the human neurodegenerative disease cerebello-cerebral atrophy type 2 (PCCA2) [68,81]. Sphingolipid metabolism is also perturbed in AD, PD, and HD. With the emerging role of ceramide and sphingosine-1-phosphate (S1P) as cell-signaling hubs in the pathophysiology of several neurodegenerative diseases, unified therapeutic approaches are possible. It is not known if, in yeast or human cells devoid of VPS13 proteins, the sphingolipid homeostasis is disturbed, which remains to be analyzed. However, deficiency of Vps13A negatively affects the PI(4)P pool, which affects the synthesis of complex sphingolipids in mammalian cells [82]. Thus, it is possible that VPS13 negatively affects sphingolipid homeostasis and the drugs selected here, tolcapone and flavonoids, alleviated this defect.

\section{Conclusions}

The screening of drug candidates using yeast models of neurodegenerative diseases has already proved efficient to isolate compounds that were later shown to be active in patient-derived cells. This study revealed that tolcapone and several natural flavonoids, including luteolin, exert positive effects on a vps13 $\triangle$ yeast model of VPS13-dependent rare neurodegenerative diseases. These compounds may represent candidates for drug repurposing and dietary supplementation as a potential strategy to improve the existing symptomatic treatments of these diseases. Characterization of the mechanism of luteolin action revealed iron homeostasis and sphingolipid biosynthesis as possible targets. Our study also indicates that further research on sphingolipids in cells devoid of the Vps13 protein is critical 
to better understand the pathogenesis of VPS13-dependent rare neurodegenerative diseases and to develop effective therapeutic strategies.

Supplementary Materials: The following are available online at http://www.mdpi.com/2073-4425/11/7/828/s1, Figure S1: Comparison of chemical suppressors of vps13 $\Delta$ growth defect upon SDS stress; Figure S2: Comparison of the action of flavonoids on wild-type and vps13 strains upon cadmium stress; Figure S3: Signaling pathway involving FET3 and CTH2 genes responding to iron deficiency is not activated in vps13 $\triangle$ cells; Table S1: List of $S$. cerevisiae strains used; Table S2: List of chemical compounds used; Table S3: List of plasmids used.

Author Contributions: Conceptualization, T.Z. and J.K.; methodology, P.S., K.F. and D.T.-T.; validation, P.S., K.F., R.M. and T.Z.; formal analysis, P.S.; investigation, P.S., K.F. and J.K.; resources, P.S., J.K., J.-P.d.R., R.M. and C.N.S.; data curation, P.S.; writing—original draft preparation, T.Z. and P.S.; writing—review and editing, J.K., R.M., C.N.S., K.F. and D.T.-T.; supervision, T.Z., project administration, T.Z.; funding acquisition, T.Z. All authors have read and agreed to the published version of the manuscript.

Funding: This research was funded by National Science Centre Poland, grant number UMO-2015/19/B/NZ3/01515 to T.Z., the APC was funded by the Institute of Biochemistry and Biophysics Polish Academy of Sciences and the Short Term Scientific Mission of K.F. in R.M. laboratory was funded by COST Action PROTEOSTASIS (BM1307), supported by COST (European Cooperation in Science and Technology). We acknowledge iNOVA4Health-UID/Multi/04462/2019, a program financially supported by Fundação para a Ciência e Tecnologia/Ministério da Educação e Ciência, through national funds and co-funded by FEDER under the PT2020 Partnership Agreement. Funding from the INTERFACE Programme, through the Innovation, Technology and Circular Economy Fund (FITEC) is gratefully acknowledged. This study was also supported by FCT via PTDC/BIA-MOL31104/2017 to R.M.

Acknowledgments: We would like to thank K. Ayscough (University of Sheffield, UK), V. Costa (University of Porto, Portugal) for plasmids.

Conflicts of Interest: The authors declare no conflict of interest. The funders had no role in the design of the study; in the collection, analyses, or interpretation of data; in the writing of the manuscript, or in the decision to publish the results.

\section{References}

1. Shamsi, T.N.; Athar, T.; Parveen, R.; Fatima, S. A review on protein misfolding, aggregation and strategies to prevent related ailments. Int. J. Biol. Macromol. 2017, 105, 993-1000. [CrossRef] [PubMed]

2. Liu, X.A.; Rizzo, V.; Puthanveettil, S.V. Pathologies of axonal transport in neurodegenerative diseases. Transl. Neurosci. 2012, 3, 355-372. [CrossRef]

3. Belaidi, A.A.; Bush, A.I. Iron neurochemistry in Alzheimer's disease and Parkinson's disease: Targets for therapeutics. J. Neurochem. 2016, 139, 179-197. [CrossRef]

4. Hroudová, J.; Singh, N.; Fišar, Z. Mitochondrial dysfunctions in neurodegenerative diseases: Relevance to Alzheimer's disease. Biomed. Res. Int. 2014, 2014, 175062. [CrossRef] [PubMed]

5. Jung, H.H.; Danek, A.; Walker, R.H. Neuroacanthocytosis Syndromes. Orphanet J. Rare Dis. 2011, 6, 68. [CrossRef]

6. Rampoldi, L.; Dobson-Stone, C.; Rubio, J.P.; Danek, A.; Chalmers, R.M.; Wood, N.W.; Verellen, C.; Ferrer, X.; Malandrini, A.; Fabrizi, G.M.; et al. A conserved sorting-associated protein is mutant in chorea-acanthocytosis. Nat. Genet. 2001, 28, 119-120. [CrossRef]

7. Ueno, S.I.; Maruki, Y.; Nakamura, M.; Tomemori, Y.; Kamae, K.; Tanabe, H.; Yamashita, Y.; Matsuda, S.; Kaneko, S.; Sano, A. The gene encoding a newly discovered protein, chorein, is mutated in chorea-acanthocytosis. Nat. Genet. 2001, 28, 121-122. [CrossRef] [PubMed]

8. Velayos-Baeza, A.; Vettori, A.; Copley, R.R.; Dobson-Stone, C.; Monaco, A.P. Analysis of the human VPS13 gene family. Genomics 2004, 84, 536-549. [CrossRef]

9. Rzepnikowska, W.; Flis, K.; Muñoz-Braceras, S.; Menezes, R.; Escalante, R.; Zoladek, T. Yeast and other lower eukaryotic organisms for studies of Vps13 proteins in health and disease. Traffic 2017, 18, 711-719. [CrossRef]

10. Kolehmainen, J.; Black, G.C.M.; Saarinen, A.; Chandler, K.; Clayton-Smith, J.; Träskelin, A.-L.; Perveen, R.; Kivitie-Kallio, S.; Norio, R.; Warburg, M.; et al. Cohen Syndrome Is Caused by Mutations in a Novel Gene, $\mathrm{COH1}$, Encoding a Transmembrane Protein with a Presumed Role in Vesicle-Mediated Sorting and Intracellular Protein Transport. Am. J. Hum. Genet. 2003, 72, 1359-1369. [CrossRef] 
11. Lesage, S.; Drouet, V.; Majounie, E.; Deramecourt, V.; Jacoupy, M.; Nicolas, A.; Cormier-Dequaire, F.; Hassoun, S.M.; Pujol, C.; Ciura, S.; et al. Loss of VPS13C Function in Autosomal-Recessive Parkinsonism Causes Mitochondrial Dysfunction and Increases PINK1/Parkin-Dependent Mitophagy. Am. J. Hum. Genet. 2016, 98, 500-513. [CrossRef]

12. Gauthier, J.; Meijer, I.A.; Lessel, D.; Mencacci, N.E.; Krainc, D.; Hempel, M.; Tsiakas, K.; Prokisch, H.; Rossignol, E.; Helm, M.H.; et al. Recessive mutations in VPS13D cause childhood onset movement disorders. Ann. Neurol. 2018, 83, 1089-1095. [CrossRef] [PubMed]

13. Koh, K.; Ishiura, H.; Shimazaki, H.; Tsutsumiuchi, M.; Ichinose, Y.; Nan, H.; Hamada, S.; Ohtsuka, T.; Tsuji, S.; Takiyama, Y. VPS13D-related disorders presenting as a pure and complicated form of hereditary spastic paraplegia. Mol. Genet. Genomic Med. 2020, 8, e1108. [CrossRef] [PubMed]

14. Seong, E.; Insolera, R.; Dulovic, M.; Kamsteeg, E.J.; Trinh, J.; Brüggemann, N.; Sandford, E.; Li, S.; Ozel, A.B.; Li, J.Z.; et al. Mutations in VPS13D lead to a new recessive ataxia with spasticity and mitochondrial defects. Ann. Neurol. 2018, 83, 1075-1088. [CrossRef] [PubMed]

15. Peikert, K.; Danek, A.; Hermann, A. Current state of knowledge in Chorea-Acanthocytosis as core Neuroacanthocytosis syndrome. Eur. J. Med. Genet. 2018, 61, 699-705. [CrossRef]

16. Rodrigues, J.M.; Fernandes, H.D.; Caruthers, C.; Braddock, S.R.; Knutsen, A.P. Cohen Syndrome: Review of the Literature. Cureus 2018, 10, e3330. [CrossRef] [PubMed]

17. Oliveira, A.V.; Vilaça, R.; Santos, C.N.; Costa, V.; Menezes, R. Exploring the power of yeast to model aging and age-related neurodegenerative disorders. Biogerontology 2017, 18, 3-34. [CrossRef]

18. Menezes, R.; Tenreiro, S.; Macedo, D.; Santos, C.N.; Outeiro, T.F. From the baker to the bedside: Yeast models of parkinson's disease. Microb. Cell 2015, 2, 262-279. [CrossRef]

19. Winderickx, J.; Delay, C.; De Vos, A.; Klinger, H.; Pellens, K.; Vanhelmont, T.; Van Leuven, F.; Zabrocki, P. Protein folding diseases and neurodegeneration: Lessons learned from yeast. Biochim. Biophys. Acta-Mol. Cell Res. 2008, 1783, 1381-1395. [CrossRef]

20. Dudnik, A.; Almeida, A.F.; Andrade, R.; Avila, B.; Bañados, P.; Barbay, D.; Bassard, J.E.; Benkoulouche, M.; Bott, M.; Braga, A.; et al. BacHBerry: BACterial Hosts for production of Bioactive phenolics from bERRY fruits. Phytochem. Rev. 2018, 17, 291-326. [CrossRef]

21. Chung, C.Y.; Khurana, V.; Auluck, P.K.; Tardiff, D.F.; Mazzulli, J.R.; Soldner, F.; Baru, V.; Lou, Y.; Freyzon, Y.; Cho, S.; et al. Identification and rescue of $\alpha$-synuclein toxicity in Parkinson patient-derived neurons. Science 2013, 342, 983-987. [CrossRef]

22. Dajas, F.; Rivera, F.; Blasina, F.; Arredondo, F.; Echeverry, C.; Lafon, L.; Morquio, A.; Heizen, H. Cell culture protection and in vivo neuroprotective capacity of flavonoids. Neurotox. Res. 2003, 5, 425-432. [CrossRef] [PubMed]

23. Griffioen, G.; Duhamel, H.; Van Damme, N.; Pellens, K.; Zabrocki, P.; Pannecouque, C.; Van Leuven, F.; Winderickx, J.; Wera, S. A yeast-based model of $\alpha$-synucleinopathy identifies compounds with therapeutic potential. Biochim. Biophys. Acta-Mol. Basis Dis. 2006, 1762, 312-318. [CrossRef] [PubMed]

24. Rencus-Lazar, S.; DeRowe, Y.; Adsi, H.; Gazit, E.; Laor, D. Yeast models for the study of amyloid-associated disorders and development of future therapy. Front. Mol. Biosci. 2019, 6, 15. [CrossRef] [PubMed]

25. Tardiff, D.F.; Jui, N.T.; Khurana, V.; Tambe, M.A.; Thompson, M.L.; Chung, C.Y.; Kamadurai, H.B.; Kim, H.T.; Lancaster, A.K.; Caldwell, K.A.; et al. Yeast Reveal a "Druggable" Rsp5/Nedd4 Network that Ameliorates-Synuclein Toxicity in Neurons. Science 2013, 342, 979-983. [CrossRef]

26. Kumar, S.; Pandey, A.K. Chemistry and biological activities of flavonoids: An overview. ScientificWorldJournal 2013, 2013, 162750. [CrossRef] [PubMed]

27. Panche, A.N.; Diwan, A.D.; Chandra, S.R. Flavonoids: An overview. J. Nutr. Sci. 2016, 5, e47. [CrossRef] [PubMed]

28. Wang, T.y.; Li, Q.; Bi, K.s. Bioactive flavonoids in medicinal plants: Structure, activity and biological fate. Asian J. Pharm. Sci. 2018, 13, 12-23. [CrossRef] [PubMed]

29. Naeimi, A.F.; Alizadeh, M. Antioxidant properties of the flavonoid fisetin: An updated review of in vivo and in vitro studies. Trends Food Sci. Technol. 2017, 70, 34-44. [CrossRef]

30. Rodríguez-García, C.; Sánchez-Quesada, C.; Gaforio, J.J. Dietary Flavonoids as Cancer Chemopreventive Agents: An Updated Review of Human Studies. Antioxidants 2019, 8, 137. [CrossRef] 
31. De Andrade Teles, R.B.; Diniz, T.C.; Costa Pinto, T.C.; de Oliveira Júnior, R.G.; Gama e Silva, M.; de Lavor, É.M.; Fernandes, A.W.C.; de Oliveira, A.P.; de Almeida Ribeiro, F.P.R.; da Silva, A.A.M.; et al. Flavonoids as Therapeutic Agents in Alzheimer's and Parkinson's Diseases: A Systematic Review of Preclinical Evidences. Oxid. Med. Cell. Longev. 2018, 2018, 1-21. [CrossRef] [PubMed]

32. Nabavi, S.F.; Braidy, N.; Gortzi, O.; Sobarzo-Sanchez, E.; Daglia, M.; Skalicka-Woźniak, K.; Nabavi, S.M. Luteolin as an anti-inflammatory and neuroprotective agent: A brief review. Brain Res. Bull. 2015, 119, 1-11. [CrossRef] [PubMed]

33. Figueira, I.; Menezes, R.; Macedo, D.; Costa, I.; Dos Santos, C.N. Polyphenols Beyond Barriers: A Glimpse into the Brain. Curr. Neuropharmacol. 2017, 15, 562-594. [CrossRef] [PubMed]

34. Kaniak-Golik, A.; Skoneczna, A. Mitochondria-nucleus network for genome stability. Free Radic. Biol. Med. 2015, 82, 73-104. [CrossRef] [PubMed]

35. Martínez-Pastor, M.T.; Perea-García, A.; Puig, S. Mechanisms of iron sensing and regulation in the yeast Saccharomyces cerevisiae. World J. Microbiol. Biotechnol. 2017, 33, 75. [CrossRef] [PubMed]

36. Pimentel, C.; Vicente, C.; Menezes, R.A.; Caetano, S.; Carreto, L.; Rodrigues-Pousada, C. The Role of the Yap5 Transcription Factor in Remodeling Gene Expression in Response to Fe Bioavailability. PLoS ONE 2012, 7, e37434. [CrossRef] [PubMed]

37. Cyert, M.S.; Philpott, C.C. Regulation of Cation Balance in Saccharomyces cerevisiae. Genetics 2013, 193, 677-713. [CrossRef]

38. Dix, D.R.; Bridgham, J.T.; Broderius, M.A.; Byersdorfer, C.A.; Eide, D.J. The FET4 gene encodes the low affinity Fe(II) transport protein of Saccharomyces cerevisiae. J. Biol. Chem. 1994, 269, 26092-26099.

39. Hassett, R.; Dix, D.R.; Eide, D.J.; Kosman, D.J. The Fe(II) permease Fet4p functions as a low affinity copper transporter and supports normal copper trafficking in Saccharomyces cerevisiae. Biochem. J. 2000, 351 Pt 2, 477-484. [CrossRef]

40. Waters, B.M.; Eide, D.J. Combinatorial control of yeast FET4 gene expression by iron, zinc, and oxygen. J. Biol. Chem. 2002, 277, 33749-33757. [CrossRef] [PubMed]

41. Kolakowski, D.; Kaminska, J.; Zoladek, T. The binding of the APT1 domains to phosphoinositides is regulated by metal ions in vitro. Biochim. Biophys. Acta-Biomembr. 2020, 1862, 183349. [CrossRef] [PubMed]

42. Rzepnikowska, W.; Flis, K.; Kaminska, J.; Grynberg, M.; Urbanek, A.; Ayscough, K.R.; Zoladek, T. Amino acid substitution equivalent to human choreaacanthocytosis I2771R in yeast Vps13 protein affects its binding to phosphatidylinositol 3-phosphate. Hum. Mol. Genet. 2017, 26, 1497-1510. [CrossRef] [PubMed]

43. Soczewka, P.; Kolakowski, D.; Smaczynska-de Rooij, I.; Rzepnikowska, W.; Ayscough, K.R.; Kaminska, J.; Zoladek, T. Yeast-model-based study identified myosin- and calcium-dependent calmodulin signalling as a potential target for drug intervention in chorea-acanthocytosis. Dis. Model. Mech. 2019, 12, dmm036830. [CrossRef] [PubMed]

44. Kabir, M.A.; Kaminska, J.; Segel, G.B.; Bethlendy, G.; Lin, P.; Della Seta, F.; Blegen, C.; Swiderek, K.M.; Zoładek, T.; Arndt, K.T.; et al. Physiological effects of unassembled chaperonin Cct subunits in the yeast Saccharomyces cerevisiae. Yeast 2005, 22, 219-239. [CrossRef]

45. Gietz, R.D.; Sugino, A. New yeast-Escherichia coli shuttle vectors constructed with in vitro mutagenized yeast genes lacking six-base pair restriction sites. Gene 1988, 14, 527-534. [CrossRef]

46. Sikorski, R.S.; Hieter, P. A system of shuttle vectors and yeast host strains designed for efficient manipulation of DNA in Saccharomyces cerevisiae. Genetics 1989, 122, 19-27.

47. Bach, S.; Talarek, N.; Andrieu, T.; Vierfond, J.M.; Mettey, Y.; Galons, H.; Dormont, D.; Meijer, L.; Cullin, C.; Blondel, M. Isolation of drugs active against mammalian prions using a yeast-based screening assay. Nat. Biotechnol. 2003, 21, 1075-1081. [CrossRef] [PubMed]

48. Couplan, E.; Aiyar, R.S.; Kucharczyk, R.; Kabala, A.; Ezkurdia, N.; Gagneur, J.; St Onge, R.P.; Salin, B.; Soubigou, F.; Le Cann, M.; et al. A yeast-based assay identifies drugs active against human mitochondrial disorders. Proc. Natl. Acad. Sci. USA 2011, 108, 11989-11994. [CrossRef]

49. Almeida, A.F.; Santos, C.N.; Ventura, M.R. Synthesis of New Sulfated and Glucuronated Metabolites of Dietary Phenolic Compounds Identified in Human Biological Samples. J. Agric. Food Chem. 2017, 65, 6460-6466. [CrossRef]

50. Heins-Marroquin, U.; Jung, P.P.; Cordero-Maldonado, M.L.; Crawford, A.D.; Linster, C.L. Phenotypic assays in yeast and zebrafish reveal drugs that rescue ATP13A2 deficiency. Brain Commun. 2019, 1, fcz019. [CrossRef] 
51. Antonini, A.; Abbruzzese, G.; Barone, P.; Bonuccelli, U.; Lopiano, L.; Onofrj, M.; Zappia, M.; Quattrone, A. COMT inhibition with tolcapone in the treatment algorithm of patients with Parkinson's disease (PD): Relevance for motor and non-motor features. Neuropsychiatr. Dis. Treat. 2008, 4, 1-9. [CrossRef]

52. Bors, W.; Heller, W.; Michel, C.; Saran, M. Flavonoids as antioxidants: Determination of radical-scavenging efficiencies. Methods Enzymol. 1990, 186, 343-355. [PubMed]

53. Fernandez, M.T.; Mira, M.L.; Florêncio, M.H.; Jennings, K.R. Iron and copper chelation by flavonoids: An electrospray mass spectrometry study. J. Inorg. Biochem. 2002, 92, 105-111. [CrossRef]

54. Rice-Evans, C.A.; Miller, N.J.; Paganga, G. Structure-antioxidant activity relationships of flavonoids and phenolic acids. Free Radic. Biol. Med. 1996, 20, 933-956. [CrossRef]

55. Khokhar, S.; Owusu Apenten, R.K. Iron binding characteristics of phenolic compounds: Some tentative structure-activity relations. Food Chem. 2003, 81, 133-140. [CrossRef]

56. Martins, T.S.; Pereira, C.; Canadell, D.; Vilaça, R.; Teixeira, V.; Moradas-Ferreira, P.; de Nadal, E.; Posas, F.; Costa, V. The Hog1p kinase regulates Aft1p transcription factor to control iron accumulation. Biochim. Biophys. Acta-Mol. Cell Biol. Lipids 2018, 1863, 61-70. [CrossRef]

57. Heymann, P.; Ernst, J.F.; Winkelmann, G. A gene of the major facilitator superfamily encodes a transporter for enterobactin (Enb1p) in Saccharomyces cerevisiae. BioMetals 2000, 13, 65-72. [CrossRef]

58. López-García, B.; Gandía, M.; Muñoz, A.; Carmona, L.; Marcos, J.F. A genomic approach highlights common and diverse effects and determinants of susceptibility on the yeast Saccharomyces cerevisiae exposed to distinct antimicrobial peptides. BMC Microbiol. 2010, 10, 289. [CrossRef]

59. Zhang, M.; Liu, Z.; Yu, Q.; Mao, J.; Zhang, B.; Xing, L.; Li, M. Deletion of genes encoding fatty acid desaturases leads to alterations in stress sensitivity in Pichia pastoris. FEMS Yeast Res. 2015, 15, fov020. [CrossRef] [PubMed]

60. Dickson, R.C.; Nagiec, E.E.; Wells, G.B.; Nagiec, M.M.; Lester, R.L. Synthesis of mannose-(inositol-P)2ceramide, the major sphingolipid in Saccharomyces cerevisiae, requires the IPT1 (YDR072c) gene. J. Biol. Chem. 1997, 272, 29620-29625. [CrossRef]

61. Beeler, T.J.; Fu, D.; Rivera, J.; Monaghan, E.; Gable, K.; Dunn, T.M. SUR1 (CSG1/BCL21), a gene necessary for growth of Saccharomyces cerevisiae in the presence of high Ca2+ concentrations at $37^{\circ} \mathrm{C}$, is required for mannosylation of inositolphosphorylceramide. Mol. Gen. Genet. MGG 1997, 255, 570-579. [CrossRef] [PubMed]

62. Uemura, S.; Kihara, A.; Inokuchi, J.I.; Igarashi, Y. Csg1p and Newly Identified Csh1p Function in Mannosylinositol Phosphorylceramide Synthesis by Interacting with Csg2p. J. Biol. Chem. 2003, 278, 45049-45055. [CrossRef] [PubMed]

63. Di Meo, F.; Valentino, A.; Petillo, O.; Peluso, G.; Filosa, S.; Crispi, S. Bioactive Polyphenols and Neuromodulation: Molecular Mechanisms in Neurodegeneration. Int. J. Mol. Sci. 2020, $21,2564$. [CrossRef] [PubMed]

64. Casamayor, A.; Torrance, P.D.; Kobayashi, T.; Thorner, J.; Alessi, D.R. Functional counterparts of mammalian protein kinases PDK1 and SGK in budding yeast. Curr. Biol. 1999, 9, 186-197. [CrossRef]

65. Hechtberger, P.; Zinser, E.; Saf, R.; Hummel, K.; Paltauf, F.; Daum, G. Characterization, quantification and subcellular localization of inositol-containing sphingolipids of the yeast, Saccharomyces cerevisiae. Eur. J. Biochem. 1994, 225, 641-649. [CrossRef] [PubMed]

66. Redding, K.; Brickner, J.H.; Marschall, L.G.; Nichols, J.W.; Fuller, R.S. Allele-specific suppression of a defective trans-Golgi network (TGN) localization signal in Kex2p identifies three genes involved in localization of TGN transmembrane proteins. Mol. Cell. Biol. 1996, 16, 6208-6217. [CrossRef] [PubMed]

67. Brickner, J.H.; Fuller, R.S. SOI1 encodes a novel, conserved protein that promotes TGN-endosomal cycling of Kex $2 \mathrm{p}$ and other membrane proteins by modulating the function of two TGN localization signals. J. Cell Biol. 1997, 139, 23-36. [CrossRef]

68. Fröhlich, F.; Petit, C.; Kory, N.; Christiano, R.; Hannibal-Bach, H.K.; Graham, M.; Liu, X.; Ejsing, C.S.; Farese, R.V.; Walther, T.C. The GARP complex is required for cellular sphingolipid homeostasis. Elife 2015, 4, e08712.

69. Sato, K.; Noda, Y.; Yoda, K. Kei1: A novel subunit of inositolphosphorylceramide synthase, essential for its enzyme activity and golgi localization. Mol. Biol. Cell 2009, 20, 4444-4457. [CrossRef]

70. Park, J.S.; Neiman, A.M. VPS13 regulates membrane morphogenesis during sporulation in Saccharomyces cerevisiae. J. Cell Sci. 2012, 125, 3004-3011. [CrossRef] 
71. Breslow, D.K.; Collins, S.R.; Bodenmiller, B.; Aebersold, R.; Simons, K.; Shevchenko, A.; Ejsing, C.S.; Weissman, J.S. Orm family proteins mediate sphingolipid homeostasis. Nature 2010, 463, 1048-1053. [CrossRef] [PubMed]

72. Walther, T.C. Keeping sphingolipid levels nORMal. Proc. Natl. Acad. Sci. USA 2010, 107, 5701-5702. [CrossRef] [PubMed]

73. Brice, S.E.; Alford, C.W.; Cowart, L.A. Modulation of sphingolipid metabolism by the phosphatidylinositol4-phosphate phosphatase Sac1p through regulation of phosphatidylinositol in Saccharomyces cerevisiae. J. Biol. Chem. 2009, 284, 7588-7596. [CrossRef] [PubMed]

74. Davis, D.; Kannan, M.; Wattenberg, B. Orm/ORMDL proteins: Gate guardians and master regulators. Adv. Biol. Regul. 2018, 70, 3-18. [CrossRef]

75. Muir, A.; Ramachandran, S.; Roelants, F.M.; Timmons, G.; Thorner, J. TORC2-dependent protein kinase Ypk1 phosphorylates ceramide synthase to stimulate synthesis of complex sphingolipids. Elife 2014, 3, e03779. [CrossRef]

76. Roelants, F.M.; Torrance, P.D.; Thorner, J. Differential roles of PDK1- and PDK2- phosphorylation sites in the yeast AGC kinases Ypk1, Pkc1 and Sch9. Microbiology 2004, 150, 3289-3304. [CrossRef]

77. Lee, Y.J.; Huang, X.; Kropat, J.; Henras, A.; Merchant, S.S.; Dickson, R.C.; Chanfreau, G.F. Sphingolipid signaling mediates iron toxicity. Cell Metab. 2012, 16, 90-96. [CrossRef]

78. Xue, Y.; Schmollinger, S.; Attar, N.; Campos, O.A.; Vogelauer, M.; Carey, M.F.; Merchant, S.S.; Kurdistani, S.K. Endoplasmic reticulum-mitochondria junction is required for iron homeostasis. J. Biol. Chem. 2017, 292, 13197-13204. [CrossRef]

79. Abdel Hadi, L.; Di Vito, C.; Marfia, G.; Ferraretto, A.; Tringali, C.; Viani, P.; Riboni, L. Sphingosine Kinase 2 and Ceramide Transport as Key Targets of the Natural Flavonoid Luteolin to Induce Apoptosis in Colon Cancer Cells. PLoS ONE 2015, 10, e0143384. [CrossRef] [PubMed]

80. Goins, L.; Spassieva, S. Sphingoid bases and their involvement in neurodegenerative diseases. Adv. Biol. Regul. 2018, 70, 65-73. [CrossRef]

81. Feinstein, M.; Flusser, H.; Tally, L.S.; Ben-Zeev, B.; Lev, D.; Agamy, O.; Cohen, I.; Kadir, R.; Sivan, S.; Leshinsky-Silver, E.; et al. VPS53 mutations cause progressive cerebello-cerebral atrophy type 2 (PCCA2). J. Med. Genet. 2014, 51, 303-308. [CrossRef] [PubMed]

82. Park, J.S.; Halegoua, S.; Kishida, S.; Neiman, A.M. A conserved function in phosphatidylinositol metabolism for mammalian Vps13 family proteins. PLoS ONE 2015, 10, e0124836. [CrossRef] [PubMed] 